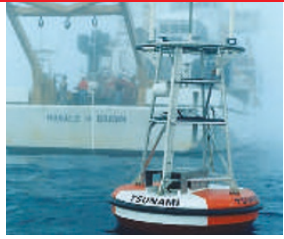

\title{
SNAPSHOT A night out in the park
}

These startled tigers were captured on film by a camera trap in Nagarhole National Park in India, as part of a nine-year monitoring study by biologist Ullas Karanth and his colleagues.

This month, the researchers report the astounding result: an average of one in four tigers living in the park dies or leaves each year - and yet, the tigers there are thriving. The study was conducted and analysed by Karanth's team from the Wildlife Conservation Society in India and by scientists from the US Geological Survey (K. U. Karanth et al. Ecology 87, 2925-2937; 2006).

How can the tigers survive despite such high annual losses? Karanth says the results bolster his hypothesis that tigers reproduce fast enough each year to make up for deaths due to poaching outside the park - as long as the big cats have enough prey

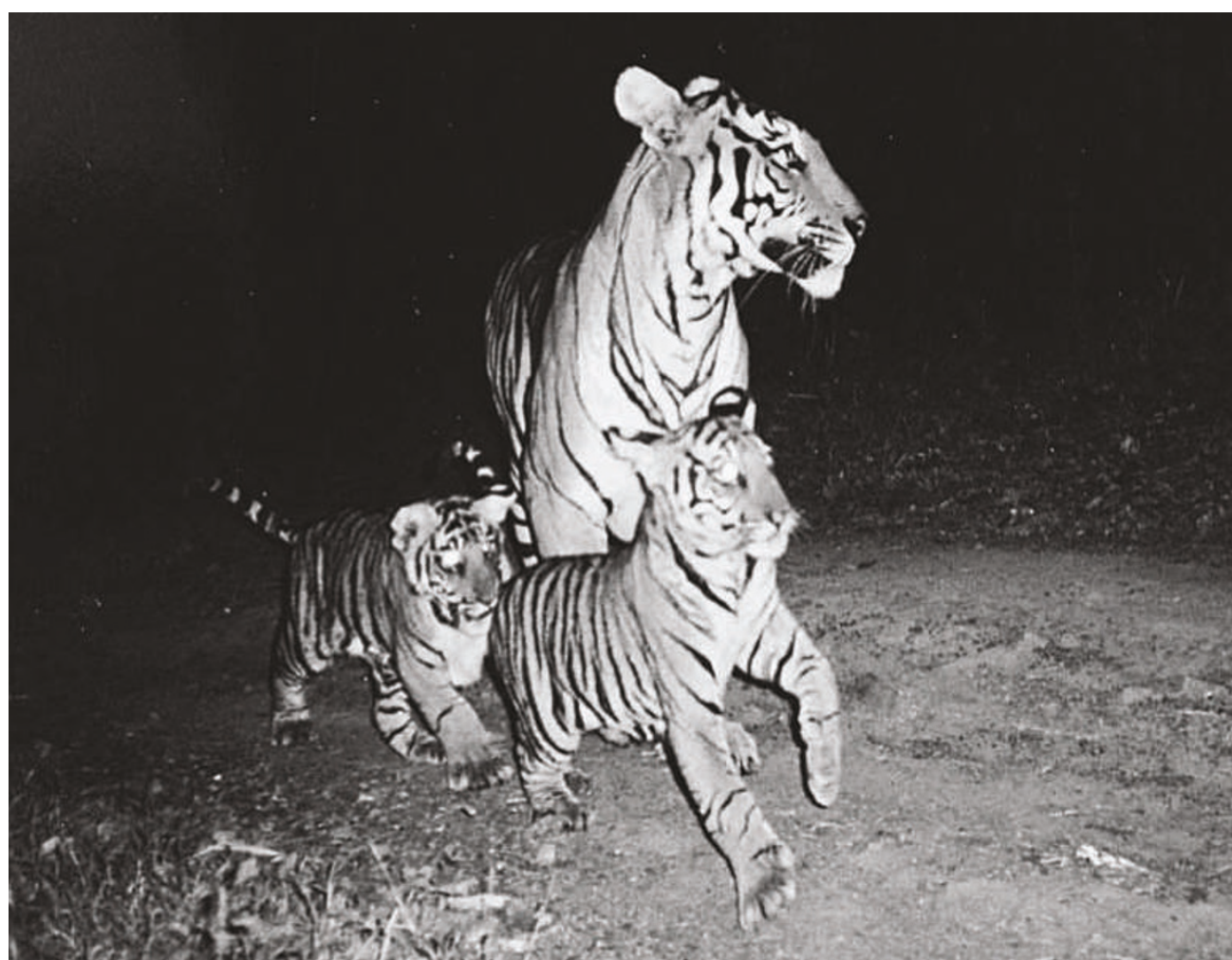

to eat and are protected inside park boundaries.

Other conservationists want governments to place more emphasis on curbing the trade in tiger parts and skins, which are in high demand in to secure healthy habitats for the tiger. So measures such as better park patrols and voluntary resettlement of people living in parks are the best way forward, he says.

Erika Check

research, to step up work on diseases that disproportionately affect the poor, and to measure research success according to its impact on human welfare. The group has delivered its statement to an influential group of technologytransfer officers from prominent US universities. And last week, it submitted the statement to a World Health Organization working group that is mapping a more sustainable strategy to develop drugs for neglected diseases.

"Universities have this lofty language in their mission statements about creating and disseminating knowledge for the public good," says Dave Chokshi, a medical student at the University of Pennsylvania in Philadelphia and a member of UAEM. "If they want that to mean anything, they have to take up these types of issues and show it's not just lip-service."

But technology-transfer officers at universities say that it's not always easy to do the right thing. Some argue that the socially responsible technology-transfer movement doesn't understand the pressures involved in marketing university inventions to potential investors.

In a deal announced this June, for instance, Yale licensed a new AIDS drug, Ed4T, to a Japanese company called Oncolys BioPharma.
Ed4T is chemically very similar to $\mathrm{d} 4 \mathrm{~T}$. But UAEM has criticized the deal, alleging that the licence doesn't do enough to secure access to the drug for the poor. The students claim that Yale seems to have reversed the course it set with the $2001 \mathrm{~d} 4 \mathrm{~T}$ agreement.

The Clinton Foundation HIV/AIDS Initiative, based in New York, has also questioned Yale about the terms of the Ed4T licence. In a response to the foundation on 26 October, Yale president, Richard Levin, outlined steps that the university has taken to promote access to Ed4T. For instance, the university does not plan to enforce its patents on the drug in some low-income countries, such as India. And it will not grant licences for companies that want to sell the drug in these nations, adds John Soderstrom, managing director of Yale's office of cooperative research.

Soderstrom says that Yale would have liked to do more, but that its hands were tied in this instance, adding that Ed4T was "a very difficult case". "We marketed this for years before anyone showed any interest in it," Soderstrom says. In fact, he argues, Yale is lucky if it can get one company interested in an invention - and that limits the university's ability to negotiate terms that ensure broad access to drugs.

"We were very excited because the company was willing to make a commitment to develop the technology and bring it to the marketplace, but we clearly weren't able to get every single term and condition into the licence agreement that we would have liked," Soderstrom says.

This is why Carol Mimura, head of Berkeley's socially responsible licensing programme, says the third plank of the Philadelphia Consensus Statement is so important. Universities must be open both to new types of arrangements, and to new ways of measuring success in partnership ventures, she says. Simply looking at the current metrics of deals done and dollars earned doesn't capture the full spectrum of benefits that universities reap from socially responsible technology transfer.

"If you measure success in terms of social impact or awareness and you count things such as gifts, research collaborations, global impact and boost to your reputation, it changes your orientation," Mimura says. "If you measure success only by the amount of royalties and fees you bring in, then your licensing practices will reflect that."

Erika Check 